\title{
A Conceptual Framework for Business Model Innovation: The Case of Electric Vehicles in China
}

\section{Koncepcyjne ramy dla modelowych rozwiązań biznesowych: przypadek samochodów elektrycznych w Chinach}

\author{
Luning Shao* Yixi Xue** Jianxin You***
}

\author{
School of Economics \&Management, Tongji University, Shanghai, 200092, China \\ E-mail: "shaoluning@tongji.edu.cn; ${ }^{* *} n k x u e y i x i @$ sina.com (correspondingauthor); \\ ***yjx2256@vip.sina.com
}

\begin{abstract}
EVs (electric vehicle), as sustainable technologies, hold the potential to achieve the sustainability of the transport system and challenge the prevailing business models of internal combustion engines (ICEs). To unlock the dominant logic of ICEs and promote the diffusion of EVs, Business model (BM) innovation is necessary. However, BM innovation for EVs still faces many obstacles. This paper makes contribution theoretically and practically by constructing a "3-7" system and proposing a two-phase conceptual framework for BM innovation of EVs. The case of Shenzhen City, China is studied to illustrate how the "3-7" system and two-phase conceptual framework is applied. Based on the case study, this paper concludes two new barriers that are not highlighted by the previous literature and makes a number of suggestions to help address the issues found in BM innovation.
\end{abstract}

Key words: Business model innovation, electric vehicles, "3-7" structure system, two-phase conceptual framework, value network

\section{Streszczenie}

Samochody elektryczne (EVs - electric vehicles), jako technologie prośrodowiskowe mogą doprowadzić do zrównoważoności całego systemu transportowego, stanowiąc tym samym wyzwanie dla dominującego modelu biznesowego tradycyjnych pojazdów spalinowych. Aby przełamać monopol maszyn spalinowych i doprowadzić do upowszechnienia samochodów elektrycznych, konieczne jest opracowanie biznesowego modelu innowacji. Niestety, w przypadku samochodów elektrycznych nadal napotyka on na wiele przeszkód. W tym artykule proponujemy rozwiązania zarówno na płaszczyźnie teoretycznej, jak i praktycznej, proponując system „3-7" i składające się z dwóch faz ramy konceptualne. W celach zobrazowania tego systemu wybrano przypadek miasta Shenzen w Chinach. Na tej podstawie w dyskusji zidentyfikowano dwie nowe bariery, który nie były dotąd omawiane w literaturze i zaproponowano szereg nowych rozwiązań, które powinny przyczynić się do rozwiązania istniejących problemów.

Slowa kluczowe: modelowa innowacja biznesowa, samochody elektryczne, system strukturalny „3-7”, dwu-fazowe ramy konceptualne, wartość sieci

\section{Introduction}

During the past two decades, researchers and practitioner are getting more and more interested in sus- tainable development, with the hope to be able to tackle with the challenges encountered by our social development. Sustainability has involved so many aspects of our life that nowadays period can be 
named as a sustainable development revolution (Pawłowski, 2003, 2008). The transport system, which is crucial for economic development, now is associated with many persistent problems such as air pollution, resource shortage, noise and it can be considered to be unsustainable in many aspects. Achieving the transition to sustainable transportation is very important for the sustainable society.

China, one of the important emerging countries, is still facing many unsustainable problems in its transport sector ranging from emissions of pollutants to depletion of resources (Shan at al., 2012). Most of these persistent problems are attributed to the overall surge of traditional ICEs and the resulting oil consumption and $\mathrm{CO}_{2}$ emission. During the past few decades in China, car ownership has increased substantially as is shown in Figure 1 (National Bureau of Statistic..., 2011). EV, as one of the sustainable technologies, is widely accepted that it may be a sustainable solution to the energy shortage and environmental pollution in the transport sector (Egbue and Long, 2012). Transition to electricity-powered vehicles holds the potential to meet the above challenges (Xue at al., 2014). The transition theory highlights that transitions are the outcome of the interplay of many areas, which involve not only technological innovation, but also other factors such as BM innovation (Rotmans et al., 2001). Generally, technological innovation is a critical driver for industry revolution, but not the only one. Sometimes, technological innovation alone is not enough to change the dominant industry logics, BM innovation can be of the utmost importance in further changing and driving industry revolution (Sabatiere et al., 2012).

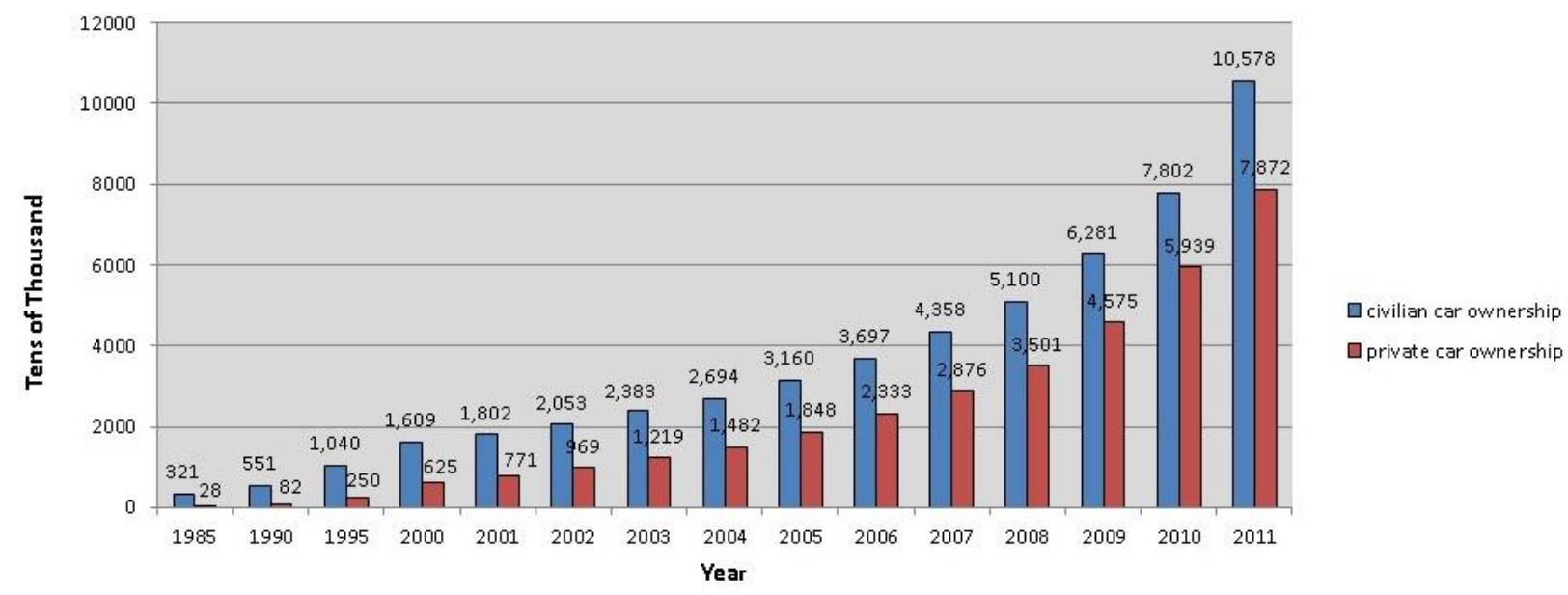

Figure 1. Car Ownership in China from 1985 to 2011

In January 2009, the Ten Cities, Ten Thousand Vehicles program was launched by Ministry of Finance (MOF), MOST, Ministry of Industry and Information Technology (MIIT), and National Development and Reform Com-mission (NDRC). A focus of this demonstration program is exploring new BMs for $\mathrm{EVs}^{1}$. Although some new BMs have been proposed during the four-year exploration, a dominant $\mathrm{BM}$ has not been formed. One important reason for this is the lack of theoretical instructions and a conceptual framework which can guide the BM innovation. So how to further explore new BMs is an urgent problem to be solved.

\section{Importance and Necessity of $\mathrm{BM}$ innovation for EVs}

The concept of BM is not newly born. In the 1990s, with the advent of internet, much more attention began to be attached to it (Demil and Lecocq, 2000). But the problem is why BM innovation gets more attention in the EV area and what are the meanings of
BM innovation for EVs? Currently, in-depth research in this connection is rarely seen.

\subsection{Discontinuous Innovations Entail New BMs}

A technological innovation, if continuous in nature, serves to improve the current product or lift its quality. Regular commercial operation still can be realized through existing infrastructure. This kind of innovation basically doesn't require transformation of BM (Cooper, 2010). However, compared with ICEs, EVs fall into the camp of discontinuous innovation. It has undergone radical changes in technology, infrastructure and energy supply, etc. Its development will bring great changes to major performance indicators for vehicles and wield decisive influence on market rules and the competitive profile. Additionally, for consumers, ICEs and EVs are two totally different products. The latter have changed customers' purchasing criteria. Therefore, development of EVs needs new BMs which are different from those of ICEs.

\footnotetext{
${ }^{1}$ Source is from MOST website, http:www.most.gov.cn, 2009.
} 


\section{2 breaking through the Technological Bottleneck} Technology itself doesn't have a sole objective value. The economic value lying hidden in technology needs to be realized in a certain form through a BM. One technology, if commercialized in different $\mathrm{BMs}$, creates varied economic value (Cherbourg et al., 2002). EV technology has achieved considerable progress since the world's first EV was introduced as early as 1834 in Scotland (Chan, 2007). However, in spite of these developments, current battery technology is still not mature, imposing many barriers on the wider diffusion of BEVs including limited driving range, longer charging time and a purchasing price higher than that of ICEs (Xue at al., 2014). Compared with ICEs, EVs have lower performance/price ratio. Therefore, BM innovation is critical to promoting the diffusion of EVs under the current technological constraints. A successful BM can offset, to a great extent, difficulties inflicted by immature technology and create more economic value.

\subsection{Establishing Self-Reinforcement Mechanisms} According to the technological lock-in theory, the path that leads to the lock-in of a technology often starts with a small historical event through which the technology can gain an initial market advantage (Cowan and Hulten, 1996). This initial advantage can create a snowballing effect through some selfreinforcement mechanisms and eventually this technology will gain a dominant position and the society, locked into the technology. In the case of ICEs, various self-reinforcement mechanisms including economies of scale, learning effect, network externality and self-adaptability, etc., as are shown in Figure 2 (Struben and Sterman, 2008), have led to its dominant position. For EV, it is necessary to break technological lock-in of ICEs and establish its own selfreinforcement mechanisms in order to achieve wider diffusion.

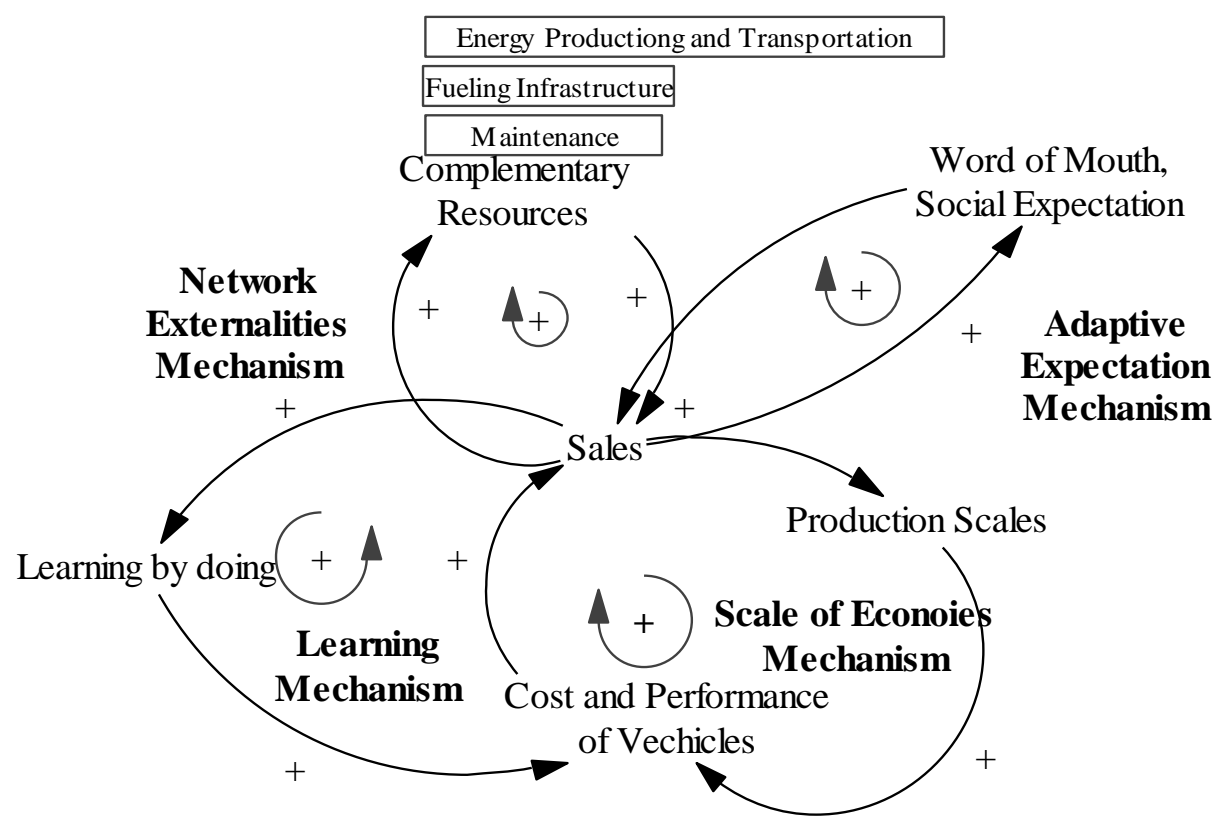

Figure 2. Lock-in Mechanisms for Automobiles

BM is an important tool for EVs to establish self-reinforcement mechanisms, because BM innovation of EVs will create a new value network for EVs, which can promote the establishment and reinforcement of the network externality mechanism. New value propositions and market segments increase consumers' adaptive expectations for EVs and serve as an impetus for EVs' diffusion in the market. Additionally, innovation of revenue model would spur the establishment and reinforcement of economies of scale and the learning effect mechanism. All of this would finally give EVs the initial market advantages and bring about positive feedback effects.

\section{Theoretical Framework}

\subsection{Development of “3-7” Structure System}

The concept of BM has been attracting substantial attention from academics and practitioners over recent years. Zott (et al., 2011) conducted a literature review about BM and found that from 1995 to 2009 , 1177 papers had been published in peer-reviewed academic journals in which BM was the essential analysis subject. However, despite the overall increase in the literature on BMs, scholars still have not reached a consensus on what a BM is (Zott et al., 2011). Many scholars study the BM without explicitly defining the concept (Pateli and Giaglis, 2005). 
BM, by definition, pertains to both static and dynamic perspectives. The former helps us construct a typology to study how different elements of BM are correlated and how such a correlation exerts an impact on the development of enterprises and the entire industry. Nevertheless, the static perspective can hardly help us understand the revolutionary process of BM innovation (Demil and Lecocq, 2010).

$\mathrm{BM}$ innovation for EVs is induced by technological innovation, meaning that BM will change with the development of EV technology (Pateli and Giaglis, 2005). The ever-changing nature of EV technology and stagedness of its industrialization determines that the BM (innovation) for EVs is staged and dynamic (Gärling and Thøgersen, 2001). In different phases of technological development and industrialization, entities and elements of the BMs for EVs undergo changes. Therefore the concept of EV BM should be defined not only by a static approach, but also a dynamic one.

Although scholars define BM based on their own research purpose, most agree that BM is the articulation between different BM components to create, deliver and realize value for consumers and thus for the firms (Tikkanen et al., 2005; Demil and Lecocq, 2010). This is also applicable to EV BM, although not specifically for EVs. As we have explained, the definition of BM for EVs should be determined by both the static and transformational approach. Building on the studies of Timmers (1998) and Teece (2010), we argue that the static definition of BM for EVs emphasizes the architecture of different BM components which describes the various actors and their roles in the new value network of EVs and explains how to create and deliver value for one or more market segments and realize value for the firms through the architecture. While the dynamic definition of BM for EVs refers to the evolution of the architecture of different BM components. The evolution emphasizes not only the change of different BM components and their relations, but also the change conducted on different levels including the industry level and firm level.

The definition of BM for EVs shows that the concept of BM components is crucial to BM. The reason for the disagreement on BM definition mainly lies in the varying opinions on what BM components include. So it is critical to define the BM components clearly in order to illustrate the BM definition. The concept of BM components is usually defined in two ways: describing the main components ex ante or inducing the components according to the specific firm. An ex ante definition has the advantage in measuring the changes in the component consistently across the firms. However, it also holds the disadvantage which assuming the same components across the different firms. To avoid the disadvantage of ex ante specification, Demil and Lecocq (2002) proposed an approach to define the $\mathrm{BM}$ components by specifying the core components which encompass different subsidiary elements. This approach can avoid the disadvantage while still can make comparison between firms.

In this paper, we adopt the above approach and specify the components ex ante based on the development practice of EVs and the research of Chesbrough and Rosenbloom (2002), Osterwalder (2004) and Teece (2010). We contribute to the definition of BM components by proposing a "3-7" structure system as is shown in Figure 3. "3" refers to three interfaces and "7" refers to the seven subsidiary elements contained in the three interfaces. The former includes customer interface, partner interface and organizational structure interface which can fulfill three functions: creating value, delivering value and realizing value. The latter refers to the seven subsidiary elements contained in the three interfaces: value proposition, market segmentation, value network, partnership, cost structure, revenue model and value chain. Each category may contain different elements to fit the study purposes of scholars.

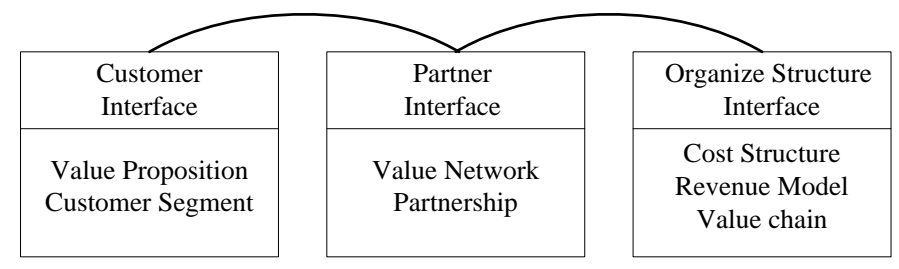

Figure 3. "3-7" Structure System of BM Components

1. Customer Interface. Realization of customer value is essential for a BM. Firm value can only be realized when customer needs are satisfied and customer value is created. Value proposition is the value that a company can create for customers by offering the company's products or (and) service (Chesbrough and Rosenbloom, 2002). Market segment indicates to whom the offerings will be delivered or marketed (Demil and Lecocq, 2002).

2. Partner Interface. This interface describes the cooperation among different actors which is necessary for the creation of value. Value network is composed of all actors in this network including supplier, customers, coalitions and the position of each actor in the network (Demil and Lecocq, 2002). Reasonable value network can improve the efficiency of delivering value to customers. Partnership focuses on how to handle the relationship among actors in order to achieve win-win results.

3. Organizational Structure Interface. This interface focuses on the internal of firms. Cost Structure is the cost that a firm has to pay in order to create and deliver value to customers. Revenue model articulates the way a firm makes money through varieties of revenue flows (Osterwalder, 2004). The difference between revenue and cost generates margin profits for firms. The concept of value chain describes the 
activities, resources within the firm and their arrangement which are necessary to value creation (Osterwalder, 2004).

\subsection{A Two-phase Conceptual Framework for BM In- novation in $E V s$}

As is explained above, BM definition for EVs has both static and transformational implications. Therefore BM innovation for EVs not only emphasizes the establishment of "3-7" structure system, but also focuses on the evolution of BM components. Most extant studies on BM innovation often select financial dimension as the study perspective and enterprises, the study subjects (Byoung et al., 2007; Desyllas and Sako, 2013), hardly incorporating the changes of external environment into the research of BM innovation. Obviously this doesn't sit with the BM innovation for EVs. Additionally, in the early literature that still exists today, dynamics in BMs emphasize that a firm changes its BM based on the capabilities and learning and the evolving conditions in the market. BM innovation is usually conducted and analyzed at the firm level. (Pateli and Giaglis, 2005; Demil and Lecocq, 2010). However, firm-level analysis unit is not very appropriate for BM innovation in EVs.

The BM for ICEs is no longer applicable to EVs. EV technology changes the power system of ICEs, and electricity-driven engines replace the internal-combustion ones. These cause the change and reconstruction of industry chain and value network in the automotive industry. Some new actors will enter the value network of EV BMs, including electricity suppliers, charging infrastructure operators, new auto manufacturers and car parts suppliers. Some incumbent actors may have to exit the value network of EV $\mathrm{BM}$ and the dominant positions of some actors in the value network of traditional ICEs may be changed. So when considering new business models for EVs, the basic questions are: who owns the vehicle or the battery? Who can participate in the new value network and who will have to exit? Who will be responsible for the operation of the infrastructure? Obviously, in this stage, the concept of BM innovation concerning EVs, used mostly at the industry level instead of the firm level, focuses on the actors in the new value network and their roles instead of the internal value chain activities within one firm. However, previous studies on BMs for EVs seldom research from this perspective. We contribute to this by proposing a two-stage conceptual framework to articulate how to promote and analyze BM innovations for EVs.

We visualize the two-phase conceptual framework in Figure 4, which shows our logic about BM development in EV industry over time. This conceptual framework embodies both static and dynamic characteristics and is composed of three parts.
As for the first part, the framework argues that BM is a dynamic concept and the BM innovation for EVs should be achieved through two phases successively: Phase I and Phase II. At Phase I, BM innovation for EVs is mainly conducted at the industry level and at the Phase II, the firm level.

As for the second part, the conceptual framework highlights the static aspect of BM innovation. In each phase, the development of BM involves the innovation of the three interfaces in the "3-7" structure system, but the focus is different. During Phase I, EV industry chain and value network for EV BM is not perfect. Who can enter the value network, what the position of each stakeholder is, which actor can hold dominant position in the EV value network, are not sure. For example, in China there are competitions between petroleum companies (China National Petroleum Corporation, CNPC) and grid companies (such as State Grid, SG) for charging infrastructure operation, as well as between grid companies and auto manufacturers for battery ownership (swapping battery or charging battery). These uncertainties make it difficult to analyze BM innovation from the perspective of a particular enterprise. So we argue that BM innovation for EVs should firstly be conducted at the industry level and its main purpose at this point should be building a partner interface of EV BM from the perspective of industry chain. After the establishment of the value network and partnership for EV BM at the industry level, BM innovation comes to Phase II. As is shown in the Figure 4, following the industry-level BM innovation, different value networks of EVs can be formed, just like the different shapes in the upper rectangle. The result of innovation in Phase I directly determines which actor can come into further BM innovation and may even influence the ways of it at the Phase II. Then at the second phase, BM innovation is conducted at the firm level and focuses on the analysis of how firms integrate internal resources and external value network to better create value for customers. BM innovation of firms in Phase I is to pin down positions in the new value network at the industry level, while in Phase II is to capture more market share and profits. It should be mentioned that although we have broadened the meaning of dynamics in the early BM innovation literature, we haven't ignored it. So for the third part of the conceptual framework, we argue that no matter how BM innovation is conducted, at industry level or firm level, BM in each phase still has original dynamic implications. BM innovation goes through the dynamic process from design and testing to development and scaling up as is shown in Figure 4. BM needs to be continually changed and developed with the change of internal and external conditions. 

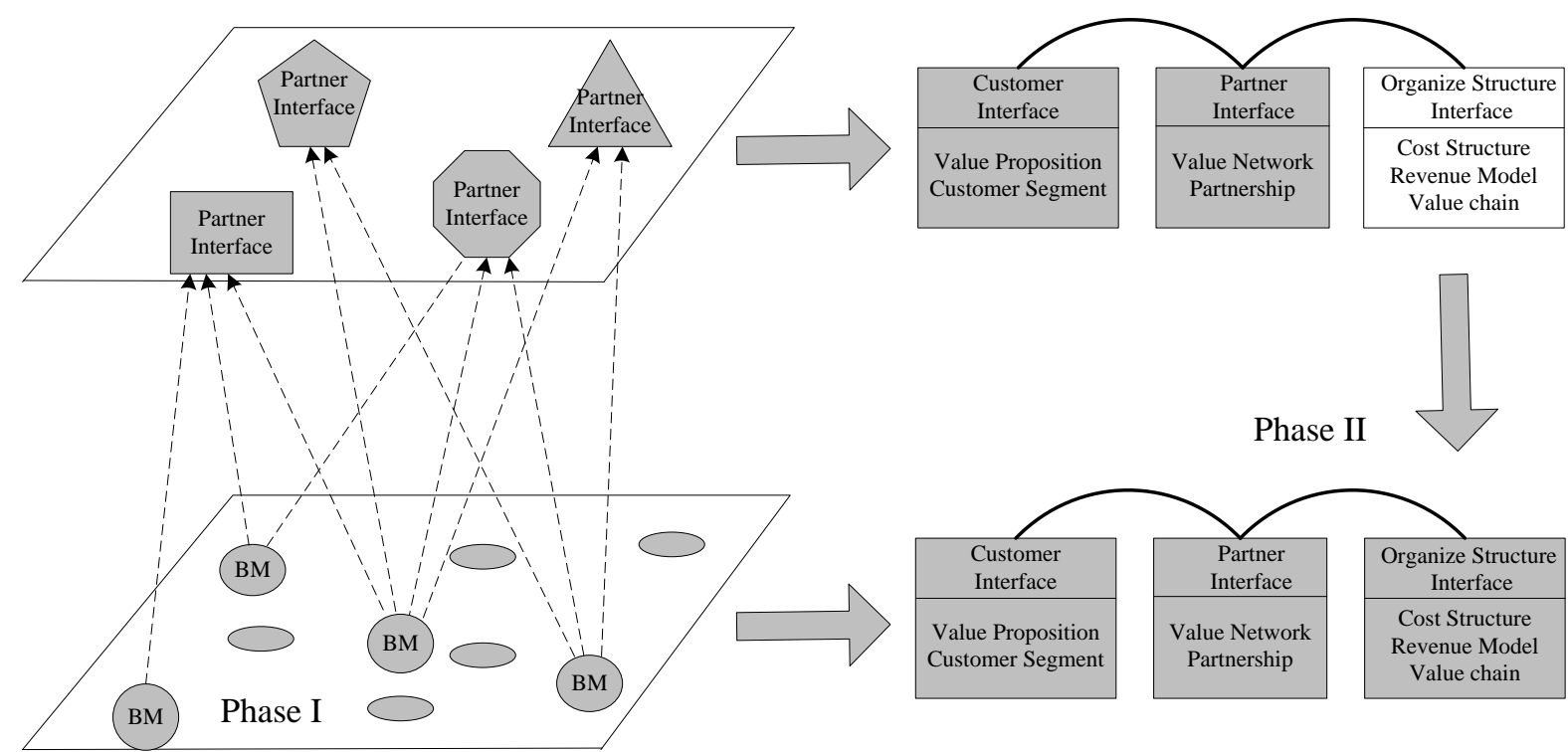

Figure 4. Two-phase Conceptual Framework for BM Innovation of EVs

\section{BM innovation Story for EVs in Shenzhen, China}

In this section, we choose the case of Shenzhen, China to illustrate how BM innovation of EVs is conducted. From this case, we can see that the "3-7" structure system and two-phase conceptual framework are useful in illustrating the process of BM innovation. it can provide guidance for the BM innovation in other places.

This paper is based on a single case study, which Sosna (et al., 2010) consider appropriate if the case is extreme, unique or revelatory. As we have described, the Chinese government launched a demonstration program Ten Cities, Ten Thousand Vehicles in 2009 and 13 cities (Batch I) were approved to carry out the demonstration, followed by 7 additional pilot cities (Batch II) and five more cities (Batch III). One aim of this program is to explore appropriate BMs for EVs through testing and implementing new $\mathrm{BMs}$ in the 25 demonstration cities. Among them, Shenzhen (SZ) is one of the dual-pilot cities: EV demonstration pilots and pilots of subsidizing private EV buyers. During the period between 2009 and2012, SZ established two different BM models in taxi and bus sectors. The BM is very representative in China and is named SZ Model and it achieved large-scale commercial operation for the first time in the areas of electric buses and electric taxis ${ }^{2}$. By June 2012, there were $3147 \mathrm{EVs}$ out on the road in SZ, registering the highest number nationwide (CMEN, 2012). So we select SZ to conduct a case study, which is consistent with the selection made by Development Research Center of The State Council ${ }^{3}$. This research is supported by the Fundamental Research Funds for the Central Universities

\footnotetext{
${ }^{2}$ Source is from National Energy Administration website. www.nea.gov.cn, 2012.
}

(2910219006) in Tongji University and Shanghai Science and Technology Development Fund-the Soft Science Research Project (13692100600) of Science and Technology Commission of Shanghai Municipality. The survey was conducted in the summer of 2012. All the data is either obtained by field investigation and face-to-face interviews with stakeholders including governments, manufacturing companies, charging infrastructure operators and uses, or by secondary source mainly from the internet.

This section describes the process by which $S Z$ Model was configured over four years (2009-2012). On a broader level, BM innovation in SZ can be divided into four phases based on the year. In the following passages, we analyze the BM innovation in the context of the proposed " $3-7$ "'structure system and two-phase conceptual framework.

\subsection{9: Start-up and Preparation Stage}

After SZ was selected as the Energy Efficiency and New Energy Vehicles Demonstration Pilot City in January 2009 by MOF, MOST, MIIT and NDRC, the city started the BM innovation process of EVs. Energy Efficiency and New Energy Vehicles Pilot City Leading Group Office of SZ (hereafter referred to as PCLGO) was set up to manage the demonstration program.

1. Market Segment. The Ten Cities, Ten Thousand Vehicles program focuses on financing vehicles used in the public service sectors such as buses, taxis, governmental fleet, sanitation and postal service vehicles. For the reason of controllability and safety, PCLGO decided to market EVs firstly in public service sectors: bus and taxi sectors, then gradually introduce it into the private car market.

\footnotetext{
${ }^{3}$ Source is from Development Research Center of the State Council website: http://www.drc.gov.cn, 2012.
} 
2. Value Network. In June 2009, Admission Management Rules for the Auto Manufacturers and Products of New Energy Vehicles (Admission Rules) was released by MIIT and in July 2009, Recommendation List of Vehicle Types for the Demonstration program of Promoting Energy Efficiency and New Energy Vehicles- ${ }^{\text {st }}$ part (Recommendation List) was released. BYD Company was considered eligible to produce EVs for the demonstration project. In the Recommendation List-3rd part, Shenzhen Wuzhou Dragon Automobile Co., Ltd (WZD) also got the qualification. BYD and WZD are both located in SZ and therefor they become actors in the new value network of EV BM in SZ as EV manufactures and suppliers. China Southern Power Grid (CSPG), controlled by the central government and formally established on December 29, 2002, is mainly operating in transmission and distribution business and the geographical range covers Guangdong, Guangxi, Yunnan, Guizhou and Hainan provinces. In 2009, CSPG actively cooperated with government, research institutes and related enterprises, and was granted the qualification to build and operate EV charging infrastructure. By the end of 2009, CSPG had developed seven EV charging technology standards and established two charging stations (Dayun, Hexie charging stations) and 134 charging poles ${ }^{4}$. CSPG is also responsible for electricity supply in the new value network.

In 2009, BM innovation of EVs in SZ focused on selecting actors who can participate in the value network and the main market segment.

\subsection{0: Design and Development Stage}

1. Value Proposition. In June 2010, SZ was selected as one of the pilot cities in which private EV buyers are subsidized. According to Interim Measures to Financial Subsidies Pilot for Private Purchase of New Energy Vehicles issued by MOF, MOST, MIIT and NDRC, the central government will provide subsidies to EV manufacturers or battery leasing companies in SZ, Shanghai, Changchun, Hangzhou and Hefei $^{5}$. The subsidy standards are made according to the power energy of the battery pack, 3000 RMB / $\mathrm{kWh}$. The maximum subsidy for a PHEV is 50,000 RMB and 60,000 RMB for a BEV. Subsequently, SZ local government officially released Subsidy Policy on Private Purchase of New Energy Vehicle, making SZ the first among the 5 dual-pilot cities to formulate the local subsidy policy. According to this policy, SZ local government would subsidize EV manufacturers with a maximum of 30,000 RMB for a PHEV and 60,000 RMB for a BEV ${ }^{6}$. Central and local subsidies can effectively solve the problem of higher price and are helpful to value proposition innovation. Compared with ICEs, initial price of EVs are almost the

\footnotetext{
${ }^{4}$ Source is from State-owned Assets Supervision and Administration Commission of the State Council website: http://www.sasac.gov.cn, 2009.
}

same. But EVs are more energy-saving, environment-friendly and induce lower use costs. As regards the charging problem for EV users, CSBG is responsible for constructing charging poles in the residential parking place.

2. Market Segment. Bus companies including Shenzhen Bus Group Co., Ltd (SBG), Shenzhen Eastern Bus Company (SEBC) and Shenzhen Western Bus Company (SWBC) are among the target customers for EV BM in SZ. Bus companies use electric buses produced by BYD and WZD. In May 2010, Shenzhen Pengcheng Electric Taxi Co., Ltd (hereafter referred to as PCET), the first electric taxi company in China, was founded by SBG and BYD. PCET buys BEVs-BYD E6 and BYD is responsible for the maintenance. By 2012 PCET had purchased 300 BYD E6 for taxi operation.

3. Value Network. In 2010, CSPG continued to build new charging stations and charging poles, while another company - China Potevio - began to compete for the qualification of charging operation system operators. China Potevio is also a controlled by the central government and its main operation business is information service. After strategic game among different parts, SZ local government granted China Potevio the qualification. Charging stations built and operated by China Potevio mainly provide charging or swapping battery service to electric buses and charging stations set up by CSPG mainly provide charging service to electric taxis or other private EV vehicles.

\subsection{1: Further Development Stage}

Value proposition and value network. In 2011, Shenzhen Model has taken shape. Shenzhen Universiade was held in August, 2011 and 2011 electric buses were operated in the event. To solve the problem of capital shortage for bus companies, Bank of Communications Financial Leasing Co., Ltd. (BOCFL) participated in the network value and offer financial leasing service. In July 2011, with the coordination and mobilization of SZ local government, SBG, SEBC, SWBC, WZD, BYD, China Potevio and BCFL signed a finance lease contract according to which BCFL would buy 1133 electric buses from BYD and WZD. During the purchasing process, China Potevio was responsible for the selection of electric bus styles and assessment of bus quality. Then BCFL leased the buses to three bus companies who can independently operate the buses after paying rents for 8 years. This BM innovation is the first one to introduce a third-party finance company into the value network and the BM for electric buses is thus established.

\footnotetext{
5 Source is from Ministry of Finance website: http://www.mof.gov.cn, 2010.

6 Source is from Shenzhen Government website: www.sz.gov.cn, 2010.
} 


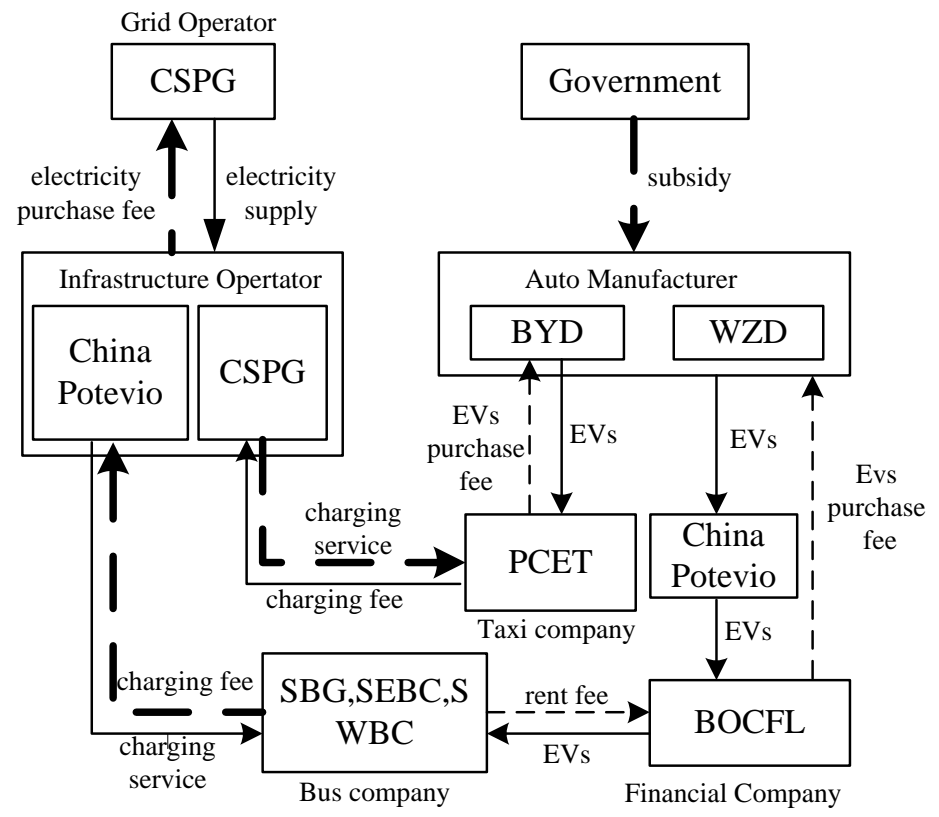

Figure 5. Business Models for EVs in SZ

\begin{abstract}
4.4 2012: Scaling-up and Further Exploitation Stage In this year, SZ Model gradually scaled up. More end users including private consumers purchased EVs and governmental fleets. By June 2012, there were altogether 2112 electric buses, 300 electric taxis, 20 electric government vehicles and 751 private $\mathrm{EVs}^{7}$. Charging infrastructure operators had built 5 charging stations and 2512 charging poles in 58 residential areas. Now BYD and CSPG are making preparation to cooperate in the area of vehicle information management.
\end{abstract}

\section{Discussion}

Based on the above analysis, we summarize the $S Z$ Model in Figure 5. Solid lines represent products/service flow and dotted lines, capital flow. The bold dotted line indicates that the capital flow has not been commercialized. From Figure 5 we can see the establishment of value network is the focus of BM innovation in SZ and BM innovation is still in Phase I by now. Overall, BM innovation is mainly conducted on industry level and the aim of BM innovation for related actors is to enter the new value network. During the four years from 2009 to 2012, BM innovation in SZ mainly addressed the following questions: Who owns the vehicles and battery? How to fuel batteries, by charging or swapping? Who builds the charging poles for customers and who acts as the operator of charging (swapping) stations? How to organize a win-win distribution mechanism so as to mobilize related stakeholders? BM innovation has not really entered the firm level, so the organizational structure interface has not really achieved innovation. As Figure 5 shows, auto manufacturers such as BYD and WZD cover their production costs mainly by financial subsidies. The capital flow between grid operator and infrastructure operator is more or less virtual by now, because in China the electricity price is under government supervision and up to now SZ local government has not made any specific provision about the electricity purchase fee. The capital flow between infrastructure operator and taxi and bus companies has not been commercialized. In SZ the charging pricing system currently is TOU (time-of-us) based: 1.0064 $\mathrm{RMB} / \mathrm{kWh}$ between 23:00 pm and 07:00 am, and $0.2495 \mathrm{RMB} / \mathrm{kWh}$ in valley time. Under such a charging price system, charging infrastructure operators cannot be profitable. So the charging fee is actually never paid by the taxi and bus companies because the pricing system is still under discussion and changes may be made.

The Shenzhen case is just the application of our proposed two-phase conceptual framework. We argue that value network establishment is vital and should be the first step for BM innovation of EVs. Two-conceptual framework is necessary to analyzing new technology-induced BM innovation which can lead to dramatic changes of the whole industry.

BM innovation always faces barriers. This is the same with the Shenzhen case. In the previous literature, several authors have highlighted the barriers to $\mathrm{BM}$ innovation, e.g. traditional dominant logic that hampers the exploration of a variety of new BMs, tensions with traditional configurations of firm resources, resistance of managers fearing negative results for their own business from a new BM, con-

\footnotetext{
${ }^{7}$ Source is from http://www.cmen.cc, 2012.
} 
flicts with established BMs that still are more profitable than innovative new ones, etc. (Amit and Zott, 2001; Chesbrough and Rosenbloom, 2002; Chesbrough, 2010; Sosna et al., 2010). However, in analyzing the SZ case we discovered some barriers to BM innovation which the early literature does not heed and which may help facilitate the success of $\mathrm{BM}$ innovation.

1. Barrier to value proposition innovation. Here we do not highlight the dominant logic barrier to value proposition innovation as the previous studies did, but stress the barriers inflicted by imperfect new technology. Generally, the new technology or new product can either offer value proposition of lower cost or better performance compared with the tradition technology/product. However, EVs have lower performance/price ratio against ICEs. A more prominent value proposition of $\mathrm{EVS}$ is environmentfriendliness, although this alone is not enough for large-scale diffusion. From the SZ case we can see that SZ model does not offer any special value proposition other than the environmental proposition and the barrier posed by higher initial price is largely removed by the financial subsidy. Although some cases like the Hangzhou Model or Better Place solve the problem of high purchasing price by adopting swapping-battery model, this actually compromises customers' ownership of the whole vehicles.

2. Barrier to appropriate profit distribution. Establishment of a value network is important for BM innovation, but it is difficult when considering the strategic seesaw among different stakeholders, especially for EVs. The product attributes of EVs determine that the value network of BM involves too many stakeholders. The key to building the value network is to decide who can participate in the network and whether the stakeholders in the network can deliver win-win results. SZ and other cases in China show that energy suppliers, infrastructure operators, auto manufacturers and batter suppliers still have different opinions on BM innovation. For example, auto manufacturers advocate the batterycharging BM and grid operators favor the batteryswapping BM, who should get financial subsidies in the new BM, and who has the qualification for infrastructure operation, etc. Strategic seesaw among stakeholders results in the uncertainty of the profit distribution mechanism, thus posing obstacles to organizational structure interface innovation just as the case in SZ model.

\section{Conclusion and suggestions}

This article contributes to the BM innovation research by adopting a dynamic perspective which holds that BM development not only means constant fine tuning based on exploration and exploitation, but also highlights the necessity of analysing BM innovation at both the macro (industry) and micro (firm) level. By introducing the SZ case, we try to integrate $\mathrm{BM}$ theory with the BM innovation practices so as to help promote BM innovation for EVs. Drawing from the case study, this paper offers the following suggestions for BM innovation in EVs.

1. A powerful organizer or mobilizer is important for BM innovation in Phase I. In our case, SZ Development and Reform Commission (SZDRC) directly carried out the BM innovation and played a critical role in the partner interface innovation. From 2009 to 2012, SZDRC had organized and mobilized many actors to participate in the establishment of the value network. In China, DRC is responsible for the organization and implementation of the national economic and social development strategies and price regulation, coordinating and solving major issues in economic operations. So it is relatively easier for SZDRC to accommodate the interests among different stakeholders. A powerful organizer can also be a company or other organizations as long as it has enough power to promote the innovation of partner interface.

2. Market segments should be different in Phase I and Phase II. At Phase I, the market segments should be narrowed and focused. EVs' product attributes determine that once the consumer develops a suspicious attitude towards the product, the initial diffusion will fail, and it is of little probability to get customers' recognition again (Egbue et al., 2012). Besides, BM innovation at Phase I focuses on the partner interface and is conducted at the industry level, so it is hard for individual firms to offer outstanding value propositions to customers. We argue that in Phase I market segments should focus on public service sectors, environment-friendly enterprises, or some special private consumers such as multi-car households, which is consistent with the research result of Gärling and Thøgersen (2001). In Phase II, market segments have two different implications. From the perspective of the entire industry, market segments should extend from specific consumers to all consumers in the EVs market. From the perspective of the individual firm, it indicates that the firm should search for its own target customers based on its strategy.

3. Value propositions should be multi-dimensional. Innovation on EVs' value proposition needs to go beyond the traditional proposition of cost advantage and superior performance because of the defective technology and excessive price. Our case shows that environmental advantage or low use cost alone is not attractive to private customers. It has already been pointed out by existing literature that the purchase cost has even a greater impact on the consumers' decision to buy cars. Hardly any of them can rationally and thoroughly weigh the cost throughout the car's entire life cycle (Turrentine et al.). Besides, low cost to use is unsustainable. Overly low cost to use is based on relatively low price of charging service which will adversely affect the benefits of infrastructure operators, thus disrupting the sustainability of 
BM for EVs. This paper holds that the value propositions of EVs should be multi-dimensional. Compared with traditional ICEs, the most distinct value proposition of EVs lies in environment-friendliness. Except that, EVs should be endowed with new connotations and cultural implications so as to convey such a message to consumers: buying EVs epitomizes a person's refined cultural taste and dignity. Additionally, the value proposition of EVs needs to shift its focus from product to product-service. Efforts should be made to score groundbreaking improvements in price, performance, insurance and maintenance, etc.; the value proposition of EVs should emphasize solutions for integration of personal transportation; measures should be taken to realize zero-emission and zero-congestion of personal transportation through the synthetic use of vehicle network, smart grid and internet, etc.; the scope of personal transportation needed to be extended so as to develop certain kinds of service such as the wireless network for transportation and social intercourse.

4. Suggestions for the establishment of partner interface of EVs. 1) Innovative approaches need to be adopted to construct the value network. Since the value network of new energy vehicle will incorporate some new entities, efforts should be made, during the reconstruction of the value network, to go beyond the ideological framework of the value network for traditional ICEs and seek the possibility of reconstruction on a larger scale so as to generate more opportunities. Batter place is an example of constructing a value network totally different from that of traditional ICEs. Kley (et al., 2011) adopted the morphological analysis method to find a variety of value network combinations. Interested readers can refer to it. 2) Different stakeholders should reinforce communication and exchanges and forge a coalition to transfer and share profits. 3) Both of the top-down and bottom-up methods should be taken to promote the establishment of profit distribution mechanism. With the former, the profit distribution mechanism can established under the promotion of a certain entity; while with the latter, the mechanism can be built up progressively through the accumulation of development experience and the Learning by Doing mechanism (Kaltoft, 2007). 4) Central and local governments should direct the coordination and cooperation between stakeholders through policies, laws, regulations, standards, fiscal subsidies and taxation, etc. 5) The development of EVs, to a large extent, aims at realizing sustainable social development and addressing energy and environmental crises. Therefore, in the process of establishing the profit distribution mechanism, stakeholders need to consider the integration of economic, social and environmental elements instead of taking self-interest or profit maximization as the sole objective.

\section{References}

1. AMIT R., ZOTT C., 2001, Value Creation in Ebusiness, in: Strategic Management Journal, vol. 22, p. 493-520.

2. BYOUNG G. K., JEON N. J., LEEM C. S., KIM B. W., LEE S. H, 2007, A Business Model Feasibility Analysis Framework in Ubiquitous Technology Environments, in: International Conference on Convergence Information Technology, Gwangju, Korea, p. 36-42.

3. CHAN C.C., 2007, The State of the Art Electric, Hybrid, and Fuel Cell Vehicles, in: Proceedings of the IEEE, vol. 95, no.4, p. 704-718.

4. CHESBROUGH H., 2010, Business Model Innovation: Opportunities and Barriers, in: Long Range Planning, vol. 43, no. 2 -3, p. 354-363.

5. CHESBROUGH H., ROSENBLOOM R. S., 2002, The Role of the Business Model in Capturing Value from Innovation: Evidence from Xerox Corporation's Technology Spin-off Companies, in: Industrial and Corporate Change, vol. 11, no. 3, p. 529-555.

6. COOPER L. G., 2000, Strategic Marketing Planning for Radically New Products, in: Journal of Marketing, vol. 64, no. 1, p. 1-16.

7. COWAN R., HULTEN S., 1996, Escaping Lock-in: The Case of the Electric Vehicle, in: Technological Forecasting \& Social Change, vol. 53, p.61-79.

8. DEMIL, B., \& LECOCQ, X., 2010, Business Model Evolution: In Search of Dynamic Consistency, in: Long Range Planning, vol. 43, p. 227-246.

9. DESYLLAS P., SAKO M., 2013, Profiting from Business Model Innovation: Evidence from Pay-As-You-Drive Auto Insurance, in: $R e$ search Policy, vol. 42, no. 4, p. 101-116.

10. EGBUE O., LONG S., 2012, Barriers to Wide Spread Adoption of Electric Vehicles: An Analysis of Consumers' Attitudes and Perceptions, in: Energy Policy, vol.48, p.717-729.

11. FREEMAN R. E., Strategic management: A stakeholder approach, Pitman, Boston, 1984.

12. GÄRLING, A., THØGERSEN J., 2001, Marketing of Electric Vehicles, in: Business Strategy and Environment, vol. 10, no. 1, p. 53-65.

13. KALTOFT R., BOER H., CANIATO F., GERTSEN F., MIDDEL R., NIELSEN J.S., 2007, Implementing Collaborative Improvement-Top-down, Bottom-up or Both, in: International Journal of Technology Management, vol. 37, no. 3/4, p. 306-322.

14. KLEY F., LERCH C., DALLINGER D., 2011, New Business Model for Electric Cars-A Holistic Approach, in: Energy Policy, vol. 39, p. 3392-3403.

15. LIU Y. Q., KOKKO A., 2013, Who Does What in China's New Energy Vehicle Industry, in: Energy Policy, vol. 57, p.21-29. 
16. NATIONAL BUREAU OF STATISTICS OF CHINA, China statistical yearbook, China Statistics Press, Beijing 2011.

17. OSTERWALDER A., The Business Model Ontology-A Proposition in a Design Science Approach, Switzerland: University of Lausanne 2004.

18. PATEli A. G., GIAGLIS G. M., 2005, Technology Innovation-induced Business Model Change: A Contingency Approach, in: Journal of Organizational Change Management, vol. 18, no. 2, p.167-183.

19. PAWŁOWSKI A., Introducing Sustainable Development - a Polish Perspective, in: Environmental Engineering Studies, Polish Research on the Way to the EU, eds. Pawłowski L., Dudzińska M.R., Pawłowski A., Kluwer Academic/Plenum Press, New York, Boston, Dordrecht, London, Moscow 2003.

20. PAWŁOWSKI A., 2008, How many dimensions does sustainable development have?, in: Sustainable Development vol. 16 no 2. p. 81-90.

21. ROTMANS J., KEMP R., ASSELT M.V., 2001, More Evolution than Revolution: Transition Management in Public Policy, in: Foresight, vol. 3, no 1, p. 15-31.

22. SABATIER V., CRAIG-KENNARD A., MANGEMATIN V., 2012, When Technological Discontinuities and Disruptive Business Models Challenge Dominant Industry Logics: Insights from the Drugs Industry, in: Technological Forecasting \& Social Change, vol. 79, p. 949-962.

23. SHAN S. D, BI X. H., 2012, Low Carbon Development of China's Yangtze River Delta Re- gion, in: Problemy Ekorozwoju/Problems of Sustainable Development, vol. 7, no 2, p. 33-41.

24. SOSNA M., TREVINYO-RODRĬGUEZ R. N., VELAMURI S. R., 2010, Business Model Innovation through Trial-and-error Learning-The Naturhouse Case, in: Long Range Planning, vol. 43, no. 2-3, p. 383-407.

25. STRUBEN J., STERMAN J. D., 2008, Transition Challenges for Alternative Fuel Vehicle and Transportation Systems, in: Environment and Planning B: Planning and Design, vol. 35, p. 1070-1097.

26. TEECE D.J., 2010, Business Models, Business Strategy and Innovation, in: Long Range Planning, vol. 43, p. 172-194.

27. TIKKANEN H., LAMBERG J. A., PARVINEN P., KALLUNKI J. P., 2005, Managerial Cognition, Action and the Business Model of the Firm, in: Management Decision, vol. 43, no. 6 , p. 789-809.

28. TIMMERS P., 1998, Business Models for Electronic Markets, in: Electronic Markets, vol. 8, no. 2, p. 3-8.

29. TURRENTINE T.S., KURANI K.S., 2007, Car Buyers and Fuel Economy, in: Energy Policy, vol. 35, no. 2, p. 213-1223.

30. XUE Y. X, YOU J. X, SHAO L. N, 2014, Understanding socio-technical barriers to sustainable mobility-Insights from Demonstration Program of EVs in China, in: Problemy Ekorozwoju/ Problems of Sustainable Development, vol. 9, no 1, p. 29-36.

31. ZOTT C., AMIT R., MASSA L., 2011, The Business Model: Recent Developments and Future Research, in: Journal of Management, vol. 37, no. 4, p. 997-1018. 
